\title{
ISSN 2332-287X
}

\section{Antigens Unmasking Using Organic Solvents for ABO Blood Typing Ofputrefied and Adipocere Bod- ies Blood Samples During Forensic Autopsies}

Saharan S$^{1}$. and Goyal A. K ${ }^{2 *}$, Gupta M, Sandhu N

Research Article

${ }^{1}$ Forensic Science Lab, Department of Zoology, Kurukshetra University, Kurukshetra, India.

${ }^{2 *}$ Reproductive Physiology Lab, Department of Zoology, Kurukshetra University, Kurukshetra, India.

\begin{abstract}
During present work an attempt was made to unmask antigens in putrefied and adipocere blood samples by treating them with organic solvents for better results in ABO blood typing.Nineputrefied and adipocerous bodies blood samples were obtained from DFSL laboratory, New Delhi, India.Each sample was divided into two groups: Control and Experimentaland were proceeded for in vitro protocol. The Control group which was not treated with any organic solvents does not showed agglutination. The Experimental group treated with different organic solution showed agglutination. Maximum agglutination was observed in sample treated with absolute ether in a duration dependent manner.
\end{abstract}

Keywords: Putrefied,Adipocerous,ABO Blood Typing, Organic Solvent.

*Corresponding Author:

Atul Kumar Goyal, Ph.D.

Research scholar, Department of Zoology, Kurukshetra University, Kurukshetra, India.

Email: atlgyl@gmil.com

Recieved: July 05,2014

Accepted: July 19,2014

Published: July 22,2014

Citation: Saharan S and Goyal A. K, Gupta M, Sandhu N (2014) Antigens Unmasking Using Organic Solvents For ABO Blood Typing Of putrefied and Adipocere Bodies Blood Samples During Forensic Autopsies. Int J Forensic Sci Pathol. 2(4), 47-49. doi: http://dx.doi. org/10.19070/2332-287X-1400014

Copyright: Goyal A. $\mathbf{K}^{\odot} 2014$ This is an open-access article distributed under the terms of the Creative Commons Attribution License, which permits unrestricted use, distribution and reproduction in any medium, provided the original author and source are credited.

\section{Introduction}

The discovery of ABO blood grouping by Land Steiner in 1900 opened a new complex field of study with many practical applications. Over the past three quarter of century, information from studies on blood grouping has been applied in medico-legal examinations. The use of blood group substances in medico-legal examinations is based on the fact that once a group is established in an individual it remains unchanged throughout his life [1]. The ABO blood group was classified into four antigens (A, B, O, and $\mathrm{AB}$ ) and six genotypes (A1, A2, B1, O1, O1v and O2)[2-5]. These antigens are widely distributed on the membranes of red blood cells [6].

Blood group has important role in the serological identification of disputed individual with biological relationship i.e. disputed paternity, maternity, kidnapping etc. Blood grouping can be done from cell (forward grouping) and serum (reverse grouping) or from whole blood [7-8]. In the forensic science field the ABO system has been a major focus because samples wereconsiderably stable to the violent conditions such as heating or drying
$[9-10,11]$

Putrefaction is the destruction of the soft tissues of the body by the action of micro-organisms (bacteria, fungi and protozoa) and results in the catabolism of tissue into gases, liquids and simple moleculesdependent on temperature and to a lesser extent on moisture. Usually, the first visible sign of putrefaction is a greenish discoloration of the skin due to the formation of sulfhaemoglobin in settled blooddue to the formation of various gases like hydrogen sulfide, carbon dioxide, methane, ammonia, sulfur dioxide and hydrogen [12].Adipocere formation typically occurs after the onset of putrefaction in warm, moist, environments and is seen as deposits of a yellowish-white, greasy, wax-like substance. Adipocere develops as the result of fat hydrolysis with the release of fatty acids [12].

The classical method of detecting ABO antigens is the hemagglutination assay. This technique is simple, inexpensive, and is sufficient for routine $\mathrm{ABO}$ blood group typing in transfusion [13]. Although ABO grouping can be easily performed from corpses when fresh blood can be obtained, the agglutinability of red blood cells against homogeneous antibodies becomes progressively weaker as the storage periods of blood or in the postmortem time of corpses increases [11].This may be due to the acquired antigens or destroying of antigenicity due to bacterial contamination and partial digestion of erythrocytes membrane by proteolytic enzymes which exist in erythrocyte membrane [14]. Therefore hemagglutination assay become undesirable in such cases because putrefaction and adipocere formation inhibits the antigen-antibody reaction.

Therefore present study was conducted to make an attempt to unmask antigen present on putrefied and adipocere blood samples by treating them with organic solvents for better results in $\mathrm{ABO}$ blood typing.

\section{Material and Methods}

\section{Collection of Sample}

Present work was done during training period in the Delhi Foren- 
sicScience Laboratory (DFSL Rohini, Delhi). Nine Putrefied and adipocerous bodies blood samples which were on bloat stage of decomposition, were obtained from DFSL Laboratory, Delhi and a short medical history related to person also noted to be cross checked with the results.

\section{Preparation of Sample}

The blood grouping was performed by absorption elution method.The blood samples of decomposed body parts were preparedby making blood stained gauze. The samples weredried in incubator and proceed further for in vitro experiment protocol.

\section{Experiment Design}

The samples were divided into two groups: Control and Experimental. The samples in Control group were not treated with any organic solvent and samples in Experimental group were treated with different organic solvent for 12 hours and 24 hours.

\section{In Vitro Experiment Protocol}

All the samples were placed in incubator at $65^{\circ} \mathrm{C}$. After $45 \mathrm{~min}$ utes 5 to 7 threads of each sample were fixed on the cellulose acetate plate. The antiserum $\mathrm{A}, \mathrm{B}$ and $\mathrm{H}$ were added to all the samples then samples were placed at $4^{\circ} \mathrm{C}$ overnight in refrigerator.

Next day antiserum was removed from theplates by washingthem thrice with chilled normal salinefor 30 minutes each time. After washings samples were made properly dried at $50-55^{\circ} \mathrm{C}$ for 10 minutes to elute the antibodies. Then $2 \%$ indicator cells were added to the dry samples and plates were incubated at $57^{\circ} \mathrm{C}$ for 15 minutes. Thereafter plates were kept on a horizontal shaker after stipulated period of timeresults were observed under stereo microscope.

If agglutination occurred in sample in which Antiserum-A was added the blood group be-longed to group A and vice versa. By extending this logic, grouping according to $\mathrm{ABO}$ system were recorded.

\section{Results}

The Controlgroup which was subjected to absorption-elution technique without any treatment with the organic solventsdoes not showed agglutination.The Experimental group treated with different organic solution showed agglutination. The agglutination reaction was more pronounced in samples treated with organic solvents for 24 hours (Table 1) than the sample treated for 12 hours (Table 2).

The sample treated with xylene, 5\% ammonia and 25\% ammonia do not showed agglutination even after 24 hour treatment. Some samples which dipped in absolute Acetone and Acetone: ether (1:1) solution show mild agglutination reaction. Maximum agglutination was observed in sample treated with absolute ether in a

Table 1: Agglutination in samples treated with organic solvents for 12 hours. (NR)No Reaction, (+) Mild Reaction, $(++)$ Moderate Reaction, $(+++)$ Strong reaction

\begin{tabular}{|l|l|l|l|l|l|l|l|l|l|}
\hline \multirow{2}{*}{ Organic solvent } & \multicolumn{9}{l|}{ Sample Number } \\
\cline { 2 - 12 } & 1 & 2 & 3 & 4 & 5 & 6 & 7 & 8 & 9 \\
\hline Xylene & NR & NR & NR & NR & NR & NR & NR & NR & NR \\
\hline $5 \%$ ammonia & NR & NR & NR & NR & NR & NR & NR & NR & NR \\
\hline $25 \%$ ammonia & NR & NR & NR & NR & NR & NR & NR & NR & NR \\
\hline Absolute Acetone & + & NR & NR & NR & NR & NR & NR & NR & NR \\
\hline Acetone: ether $(1: 1)$ & ++ & NR & NR & NR & NR & + & + & NR & NR \\
\hline Absolute Ether & +++ & ++ & NR & + & ++ & + & NR & NR & NR \\
\hline
\end{tabular}

Table 2: Agglutination in samples treated with organic solvents for the 24 hours. (NR)No Reaction, (+) Mild Reaction, (++) Moderate Reaction, (+++) Strong reaction.

\begin{tabular}{|l|l|l|l|l|l|l|l|l|l|}
\hline \multirow{2}{*}{ Organic solvent } & \multicolumn{9}{|l|}{ Sample Number } \\
\cline { 2 - 11 } & 1 & 2 & 3 & 4 & 5 & 6 & 7 & 8 & 9 \\
\hline Xylene & NR & NR & NR & NR & NR & NR & NR & NR & NR \\
\hline $5 \%$ ammonia & NR & NR & NR & NR & NR & NR & NR & NR & NR \\
\hline $25 \%$ ammonia & NR & NR & NR & NR & NR & NR & NR & NR & NR \\
\hline Absolute Acetone & + & NR & + & NR & NR & + & NR & NR & NR \\
\hline Acetone: ether $(1: 1)$ & ++ & + & + & + & NR & ++ & NR & NR & NR \\
\hline Absolute Ether & +++ & +++ & ++ & ++ & ++ & ++ & + & NR & ++ \\
\hline
\end{tabular}

duration dependent manner.

The present observation may be due to the fact that on putrefaction the antigen present in the blood was masked by product of tissue decomposition and this cause interference in antigen-antibody reaction. Treatment of putrefied blood sample with absolute ether may dissolve those decomposition products and hence gives better result in blood typing than regular elusion method. The absolute ether does not interfere with the $\mathrm{Ag}-\mathrm{Ab}$ reaction because the result of blood typing was cross checked with the medical history of the person to which blood sample belong and they were completely matched with the experiment results.

\section{Discussion}

ABO mistyping may be occurs in blood samples of putrefied bodies due to cross-reactivity with another antibody in the ordinary absorption elution method as indicated by the earlier studies [11] but in present study showed that treatment of blood sample with absolute ether give more faithful results in blood typing. The fact that $\mathrm{ABH}$ antigens were remarkably stable to heat [9] and the 
ABO blood grouping of severely burned bodies could be performed by means of absorption elution method using the burned blood or tissue samples [11] consistent with present work because during experiment protocol samples dried in incubator at high temperature give good results.

Current results supports the earlier study in which $\mathrm{ABH}$ antigens derived from partially decomposed bodies could be detected with direct hemagglutination method by incubation the cells in a solution containing adenine and inosine or saccharose [11].

Present study contradicts the earlier findings that $\mathrm{ABH}$ antigens in blood stains on cotton cloth could be detected even after 42 weeks storage by means of absorption elution methods [10]. Earlier findings encountered discrepant results when determining the blood group of wet stains or putrefied bodies by the elution method supported by present work [11].

\section{Conclusion}

The results obtained frompresent studies indicated that the $\mathrm{ABH}$ antigens of blood sample derived from putrefied and adipocere bodies could be unmasked byincubating the sample with absolute ether solution before performing elution test. The elution test gives better result in hemagglutination when antigens become unmasked. The hemagglutination became effective after the blood sample treated with organic solvents may be because product of tissue decomposition present on blood cells gets dissolved in organic phase without affecting the antigenic properties of the samples. However further research is required to make this method more effective.

\section{Acknowledgement}

First author is highly thankful to Delhi ForensicScience Laboratory (DFSL Rohini, Delhi) for providing training and laboratory facilities to conduct present study.

Second Author is highly acknowledged to Dr. Satendra K. Yadav for reviewing the present work.

\section{References}

[1]. Neiders ME (1977). Blood group determinations in forensic dentistry. Dent Clin North Am.; 21(1):99-111.

[2]. Landsteiner K (1900) Zur Kenntnis der antifermentativen lytischen und agglutinierenden Wirkungen des Blutserums und der Lymphe.Zentralbl Bakteriol; 27: 357-362. (In Japanese)

[3]. Lewis M, Anstee DJ, Bird GWG, Brodheim E, Cartron JP, et al.(1990) Blood group terminology. The ISBT Working Party on Terminology for Red Cell Surface Antigens. Vox Sang; 58 (2): 152-69.

[4]. Daniels GL, Fletcher A, Garratty G, Henry S, Jrgensen J, et al.(2004) Blood group terminology : from the International Society of Blood Transfusion committee on terminology for red cell surface antigens. Vox Sang; 87: 304316.

[5]. Bernstein F (1924) ErgebnisseeinerbiostatistischenzusammenfassendenBetrachtung, ber die erblichenBlutstrukturen des Menschen. KlinWochenschr; 3: 1495-1497.(In Japanese)

[6]. Yamamoto F, McNeill PD, Hakomori S (1995) Genomic organization of human histo-blood group $\mathrm{ABO}$ genes.Glycobiology; 5(1): 51-58.

[7]. Qasim M, Al-AMeri A, Zaidan HK, Al-Saadi AH, Ewadh MJ (2012) Genotyping of forensic DNA sample, determining ABO blood group. IJABR.2(1):72-76

[8]. Mondal AG, Islam MA, Rahman MM, Begum D, Sultana MT (2011). Role of Blood Group Serology in the Detection, Identification and Investigation for Criminality in Bangladesh. Dinajpur Med Col J; 4(2): 83-88.

[9]. Nishi K, Tanaka N, Okazaki S, Maeda H, Tsuji T,et al.(1979). Effect of heat on blood group A and B active glycolipid extracted from AB human erythrocytes. Jpn J Legal Med.; 33:86-90.

[10]. Maeda H, Nishi K, Okazaki S, Tsuji T, Tanaka N, et al.(1979). Activity changes of blood group antigens in dried blood stains on standing. J Wakayama Med Soc; 30:211-218.

[11]. Nishi K, Rand S, Nakagawa T, Yamamoto A, Yamasaki S, et.al.(2005) ABO Blood Typing from Forensic Materials - Merits and demerits of detection methods utilized in our laboratories, and biological significance of the antigens. Anil Aggrawal's Internet Journal of Forensic Medicine and Toxicology; 6(2).

[12]. Vass AA (2001) Beyond the grave - understanding human decomposition. Microbiology Today.Nov; 28:190.

[13]. Aki K, Izumi A, Hosoi E (2012) The evaluation of histo-blood group ABO typing by flow cytometric and PCR-amplification of specific alleles analyses and their application in clinical laboratories. The Journal of Medical Investigation; 59: 143-15.

[14]. Bosmann HB (1974) Red cell hydrolase. III. Neuraminidase activity in isolated human erythrocytes plasmamembrane. Vox Sang; 26:497-512. 